\title{
PARAGRAPH DEVELOPMENT BY APPLYING LEARNING EXPERIENCE APPROACH TO ENHENCE STUDENT'S WRITING ABILITY
}

\author{
${ }^{1}$ Nila Kencana and ${ }^{2}$ Melati \\ ${ }^{1,2}$ English Education Department of Prof. Dr. Hazairin, S.H University, Indonesia \\ e-mail: ${ }^{1}$ kencananila74@gmail.com, ${ }^{2}$ melatijasmine87@gmail.com
}

Received on February, $25^{\text {th }}$, Revised on March, $28^{\text {th }}$, Published on July, $30^{\text {th }} 2020$

\begin{abstract}
The objective of the research was to find out and describe the improvement in writing skills through the Experience-based Learning Approach. The method of this research was classroom action research which was conducted in two cycles. The subject of this research was students of the 4th semester of English Education Study Program Faculty of Teacher Training and Education of UNIHAZ 2016/2017. The research instruments were the observation sheet, interview guidelines, questionnaire and test form. Based on the results of data analysis of pretest and post-test shown the significant improvement. The student average increased by 13.7 points with an increase of $20 \%$. Meanwhile, from cycle I to cycle II, the average writing ability of students increased by 2.4 points with a percentage increase of $80 \%$. Based on the learning activities which have occurred the enhancing from the first to second cycles from this research findings, it showed that LEA could improve the students' writing ability.
\end{abstract}

Keywords : Paragraph Development, LEA and Writing ability

\begin{abstract}
ABSTRAK
Tujuan dari penelitian ini adalah untuk mengetahui dan mendeskripsikan peningkatan keterampilan menulis melalui Pendekatan Pembelajaran Berbasis Pengalaman. Metode penelitian ini adalah penelitian tindakan kelas yang dilaksanakan dalam dua siklus. Subjek penelitian ini adalah mahasiswa semester 4 Program Studi Pendidikan Bahasa Inggris Fakultas Keguruan dan Ilmu Pendidikan UNIHAZ 2016/2017. Instrumen penelitian berupa lembar observasi, pedoman wawancara, angket dan formulir tes. Berdasarkan hasil analisis data pretest dan post-test menunjukkan peningkatan yang signifikan. Rata-rata siswa meningkat 13,7 poin dengan peningkatan 20\%. Sedangkan dari siklus I ke siklus II rata-rata kemampuan menulis siswa meningkat sebesar 2,4 poin dengan persentase peningkatan sebesar $80 \%$. Berdasarkan kegiatan pembelajaran yang telah terjadi peningkatan dari siklus I ke II dari hasil penelitian ini menunjukkan bahwa LEA dapat meningkatkan kemampuan menulis siswa.
\end{abstract}

Kata Kunci: Pengembangan Paragraf, LEA dan Kemampuan Menulis 


\section{INTRODUCTION}

English has become a global language for international communication (Crystal, 2003). Most multilingual societies use it as the official language in all fields, law, administration, education, etc. In connection with these facts, Minha (2005) states that as an international language, the role of English in the era of globalization is very important. The need for English proficiency has increased significantly. This can be seen through job requirements where English language skills are placed as the first priority in employee recruitment. In addition, good English proficiency is not only proposed by foreign companies, but also by local companies, because English is also used both orally and in communications written by local companies, for example in receiving foreign guests and conducting transactions.

In learning English, there are 4 main skills that students must master. The four skills are listening, speaking, reading and writing. In addition, students must also master grammar (structure) which is also an important element of language learning. The process of learning language in humans begins when humans start hearing when they are babies, then continue with speaking. Learning writing is obtained when someone learns reading, this also shows that writing skills require prior experiences obtained from reading material, observation and experience.

Among the 4 skills above, writing is considered the most difficult skill for students to learn and master from basic to advanced levels. As explained above, it is because in order to master writing skills, students must first master listening, speaking, reading, and structure skills according to their level. In addition, of course, students must master vocabulary according to their level. So having to master other language skills is one of the assumptions that writing skills are considered the most difficult.

In the English Education Study Program curriculum which is prepared based on KKNI, writing courses are given as many as 8 credits divided by 2 credits for writing I offered in semester 2, writing II 2 credits offered in semester 3, writing III 2 credits offered in semester 4 and last writing IV 2 credits offered in semester 5. This research will be conducted on students who take writing III courses in semester 4 (even) of the 2016-2017 academic year.

In the description of the writing III course in accordance with the curriculum of the English Language Education Study Program, FKIP UNIHAZ, it is stated that, "This course is a continuation of the writing 
II course, namely learning how to develop paragraphs (continued) correctly through the paragraph writing process, using strategies and methods of developing paragraphs. , students are expected to be skilled in developing paragraphs properly and correctly through exercises in the paragraph writing process using strategies and methods to develop them and mastering the application of paragraph development concepts well. From the description above, the final result of this writing III course is the existence of a good paragraph product that will be produced by students after passing this course.

One of the requirements for a student to be able to produce an essay (essay) either science or fiction is the ability to develop the main sentence (topic sentence) into a paragraph. From the paragraphs will produce an essay text and in the end produce an essay composition. So students' skills in paragraph development are very important so that they can express their thoughts in producing a writing. This writing skill becomes more of a concern because students must be prepared from the start to be able to produce a paper (thesis) at the end of their study period. As a lecturer who is given the task of fostering students in writing courses according to the author's homebased course, the writer feels responsible for guiding them from the start so that they can produce good writing according to scientific writing rules.

In the writing course II, which the author is able to in the 3rd semester of the English Language Education study program, FKIP UNIHAZ, the writer finds the fact that students are hampered by writing when they are asked to develop paragraphs. When the main sentence or the main idea of the paragraph is given or obtained, it is still difficult for them to develop it into several sentences to produce one paragraph. So that the results of student writing have not been able to develop and are still not very good. Meanwhile, paragraph development is very important in the process of producing writing (essays), because sentences produce paragraphs, and paragraphs produce essays or text.

On the basis of the problems, the writer who is also a writing subject teacher feels it is very necessary to find the approach that is felt to be the most appropriate and applicable to overcome these difficulties. One of them is by applying the experience-based writing learning approach (LEA). The assumption is that students will be younger in writing what they have experienced alone or in groups in their language than they are asked to fantasize and write. This will be the initial 
way for them to share their thoughts in developing the paragraphs they plan. This approach was used in the 1920s. This approach to early literacy has now been recognized and more widely used for the last thirty years. Especially in the context of open learning using student language and student experience before developing writing skills and listening skills.

Roach Van Hallen who is a well-known advocate for the LEA first described the approach in 1960; he shows how this strategy can create a natural bridge between spoken and written language. This strategy is very effective because it emphasizes the relationship between thought, spoken language and reading. LEA uses students' own language and their previous experiences which ensures familiarity with the content and vocabulary used.

Finally, the authors plan to conduct classroom action research in writing class III in which the author is able to improve students' abilities in developing paragraphs by applying the Learning Experience Approach.

\section{METHODOLOGY}

This research used an action research design, where the focus was carried out in class activities so that the research was in the form of classroom action research. The main objective of this study is to describe students' abilities in classroom learning, especially descriptions of improving the quality of writing learning in class. Lecturers will be able to improve student learning outcomes if the lecturer wants to look back at the learning given to his students. A student's ability to learn really depends on the actions of the lecturer. The lecturer's actions like that when recorded, then the problem reflects back, the lecturer can also be said to be classroom action research because classroom action research according to Carr and Kemmis (in McNiff, 1992: 2) is a form of collective selfreflective research. involving participants (lecturers and students) in social situations (including education) with the aim of developing a rationalization of educational practices being experienced by lecturers. Classroom Action Research according to Muchith (2009: 5).

This research was conducted on the UNIHAZ campus in the writing class III of the English Education Study Program, FKIP UNIHAZ. The subjects of this research are of course all students who take writing courses III in English Education Study Program, FKIP UNIHAZ.

The study of the learning process in the classroom consists of 4 four stages, namely: (1) planning, (2) implementing the action or action, (3) observing, and (4) reflecting. 
From this cycle, it is hoped that the data collected can be obtained in response to research problems. This research will be conducted in three cycles consisting of 4 stages, namely 1) Planning, 2) Actiing, 3) Observing, and 4) Reflecting.

According to Arikunto (2010 137), "the classroom research model (Classroom Action research) or CAR, the design can be described in Picture 1. CAR according to Kemmis and Tagart in Arikunto (2010: 137) as follows:

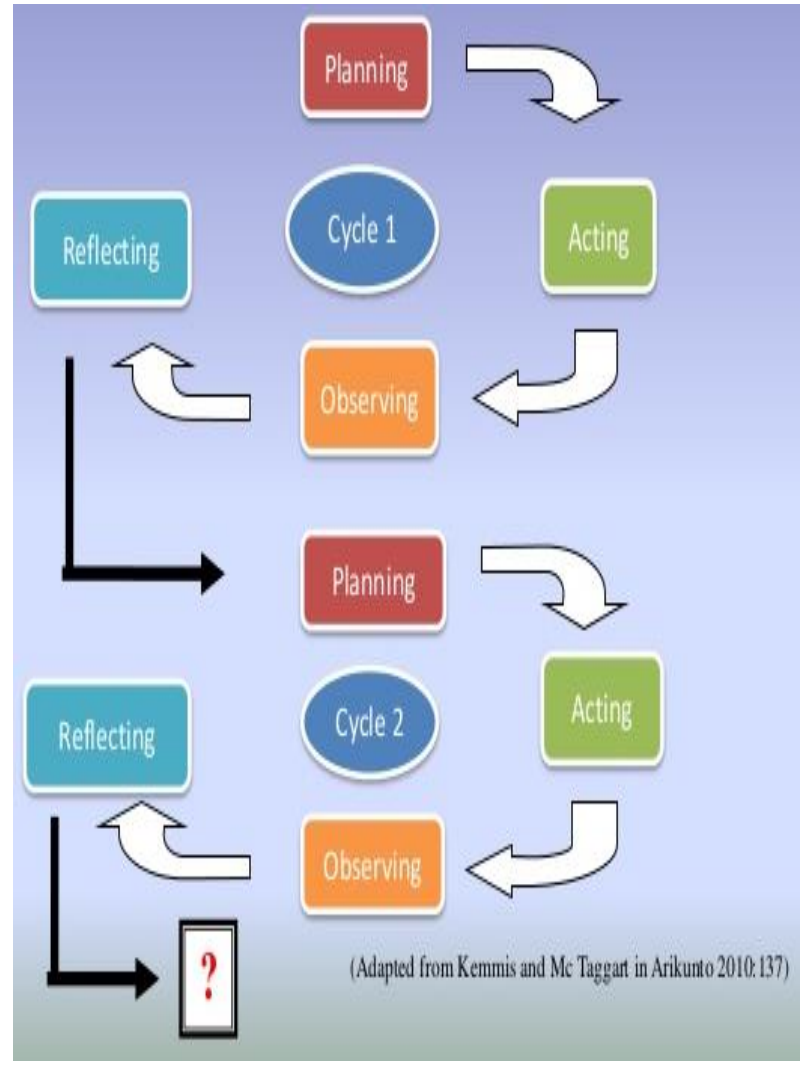

Picture 1. Adapted CAR Diagram According to Kemmis and Tagart in Arikunto (2010: 137)

\section{FINDINGS AND DISCUSSION}

Based on the pre-test score, the data shows that the pre-test mean score was 12.52 with a standard deviation of 1.517 . The lowest score obtained by students is 10 , the highest score is 14 . From the data analysis, it can be seen that students' writing skills are still very low.

Tabel 1. Descriptive Statistics

\begin{tabular}{|l|r|r|r|r|r|}
\hline & N & Min & Max & Mean & $\begin{array}{c}\text { Std. } \\
\text { Deviation }\end{array}$ \\
\hline Pretest & 5 & 10 & 14 & 2.52 & 1.517 \\
Post_Test_Siklus_1 & 5 & 13 & 18 & 14.00 & 1.732 \\
Post_Test_Siklus_2 & 5 & 15 & 20 & 18.60 & 2.191 \\
Valid N (listwise) & 5 & & & & \\
\hline
\end{tabular}

Comparison of the Results of Paragraph Writing Skills Improvement using a Learning Approach Inter-Cycle Experience Approach

To find out whether there are differences in students' writing abilities before being given the application of the Learning Experience Approach (Pre-Test) and after being given the Learning Experience Approach (Post-Test), the researcher tested the hypothesis using t-test paired sample statistics. table 2 and 3.

Based on table 2, at the df level 5 the $t$ value is 18,984 . From the table above it is known that $\mathrm{t}$ arithmetic> $\mathrm{t}$ table so it can be concluded that there are differences in 
students' writing skills before and after being given treatment. Therefore, the researchers concluded that the application of the Learning Experience Approach (LEA) approach can improve the ability to write or develop paragraphs in the Writing III course, students of the English Education study program.

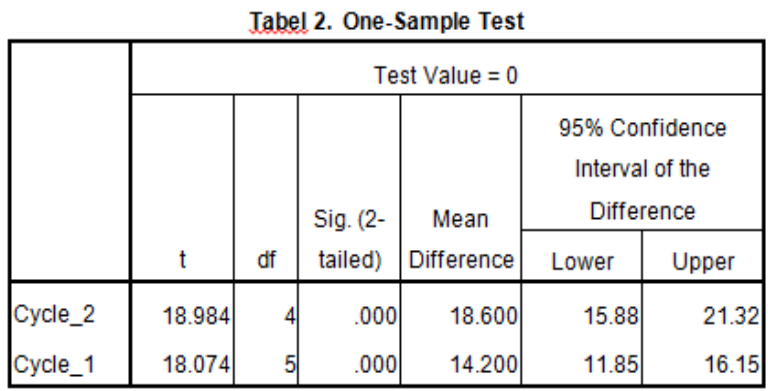

Tabel 3. Paired Samples Statistics

\begin{tabular}{|c|c|c|c|c|c|}
\hline & & Mean & $\mathrm{N}$ & $\begin{array}{c}\text { Std. } \\
\text { Deviation }\end{array}$ & Std. Error Mean \\
\hline \multirow[t]{2}{*}{ Pair 1} & Cycle_1 & 14.20 & 5 & 1.732 & .775 \\
\hline & Cycle_2 & 18.60 & 5 & 2.191 & .980 \\
\hline
\end{tabular}

\section{Cycle 1}

From the data above, it is obtained that the average writing ability in cycle 1 has not reached the specified success indicators. This is evidenced by the acquisition of an average writing ability of 14.20 with an increase of up to $20 \%$, meaning that only 1 person is successful or able to develop paragraphs using the LEA method, while $80 \%$ consists of 4 students with the title Edequate to fair, meaning that this research has not been successful. need to continue the next cycle. In other words, the application of the LEA approach to improving students' writing skills must be carried out again in cycle II.

Based on the results obtained, there are several deficiencies made by both lecturers and students. Lecturers have not been maximal in conducting learning by implementing LEA. This is because lecturers are not used to using a learning approach that requires special preparation to be enthusiastic about learning activities.

Based on the results of observations of students in cycle 1, students and lecturers were less alert in forming groups. There are some students who feel unsuitable with their group friends. So that the course of the teaching and learning process has not gone as planned because the class is also very noisy. Students are also not all enthusiastic when the lecturer gives practice questions to work on. Based on the learning results in cycle 1, the following conclusions can be drawn:

Table 4. Writing Learning Outcome for Cycle 1

\section{Indicator Pre-cycle Cycle 1}

\begin{tabular}{|lrr|}
\hline Average & $\mathbf{2 , 5 2}$ & $\mathbf{1 4 , 2 0}$ \\
\hline Improvement score & $\mathbf{2 , 5 2}$ & $\mathbf{2 0 , 0 0 \%}$
\end{tabular}


Cycle II

From the data above, it is obtained that the average writing ability in cycle 1 has not reached the specified success indicators. This is evidenced by the acquisition of an average writing ability of 18.60 with a total category of 93 and the percentage of increase reaching $80 \%$. This means that there is an increase from cycle I to cycle 2 by $40 \%$, with learning achievement ranging from $65-84 \%$, score 2 , Good Qualification, the level of learning is said to be successful. Therefore, the application of the LEA approach to improving students' writing skills does not need to be carried out again in cycle III.

Table 5. Percentage of Increase Writing Skill

\begin{tabular}{|l|c|c|c|}
\hline cycle & $\begin{array}{c}\text { Pre- } \\
\text { Test }\end{array}$ & $\begin{array}{c}\text { Post Test } \\
\text { cycle 1 }\end{array}$ & $\begin{array}{c}\text { Post Test } \\
\text { cycle 2 }\end{array}$ \\
\hline cycle & 63 & 71 & 93 \\
\hline Mean & $\mathbf{2 , 5 2}$ & $\mathbf{1 6 , 2}$ & $\mathbf{1 8 , 6}$ \\
\hline $\begin{array}{l}\text { Percentage of } \\
\text { Increase (P) }\end{array}$ & & $\mathbf{2 0 , 0 0 \%}$ & $\mathbf{8 0 , 0 0 \%}$ \\
\hline
\end{tabular}

English language skills in several integrated skills such as listening, reading, writing and speaking have been included in learning using an experience-based approach. It can be said that the experiential learning model is a learning model that pays attention to or focuses on the experiences that will be experienced by students. Students are directly involved in the learning process and students construct their own experiences so that they become knowledge. Students will get different experiences from what they have learned, this is because of the differences and uniqueness of each student's learning style.

The preparation of good paragraphs carried out by students has three conditions that must be considered, namely the elements of unity, cohesiveness, and completeness. The element of paragraph unity implies the requirement that a paragraph has only one main thought. The function of the paragraph in this case is to develop the topic. Therefore, paragraph development cannot be done haphazardly, there should be no elements that are completely unrelated to the topic, and do not support the topic. Deviation from paragraph development will be difficult for readers, will result in paragraphs ineffective.

So, ideally one paragraph contains only one main idea of one topic. All sentences in a paragraph should discuss the main idea. Solid paragraphs are supported by the use of good linguistic elements, namely the existence of good cohesion between sentences. However, this does not mean that automatically cohesive paragraphs are cohesive paragraphs. In conjunction, pronouns, repetition.

The same thing was expressed by Akhadiah, 1991: 28, The element of completeness of a paragraph refers to the 
existence of a main thought in the form of the main sentence and an explanatory mind in the form of explanatory sentences. The explanatory sentences must support the clarity of the main sentence. Paragraphs are stated as incomplete paragraphs if they are not developed properly. Therefore, the completeness element is often called development, some even call development.

In this research, students have succeeded in developing paragraphs based on technique, logically, and based on content. As an example, Lecturers provide topics about Education and Social Science. Students begin to develop paragraphs by looking for the main idea that will be the most impressive topic sentence based on their personal experience, as stated by Ramlan, 1993, the main thought or main idea is the controller of a paragraph. Seeing the results of this second cycle, thus the action hypothesis and indicators of success can be achieved so there is no need for the next cycle. Overall the results of the research can be summarized in table 5.10 and the Figure 1 below:

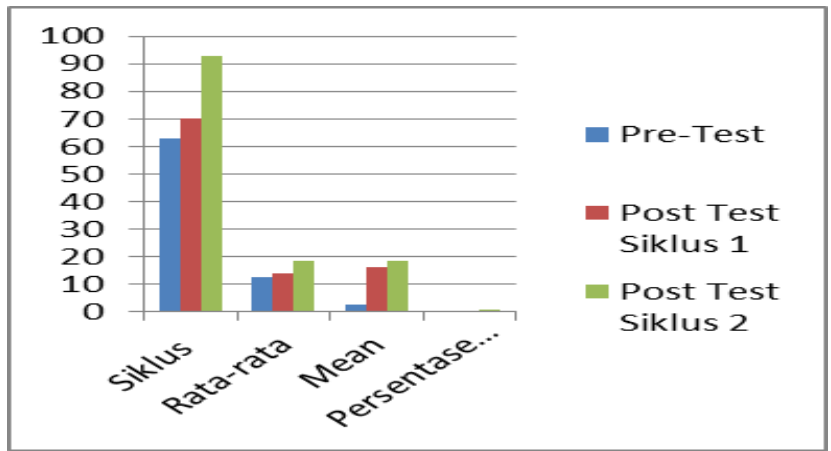

Figure 1. Graph of Improving Writing Ability Achievement With the LEA Approach in Pre-cycle, Cycle 1 and Cycle II

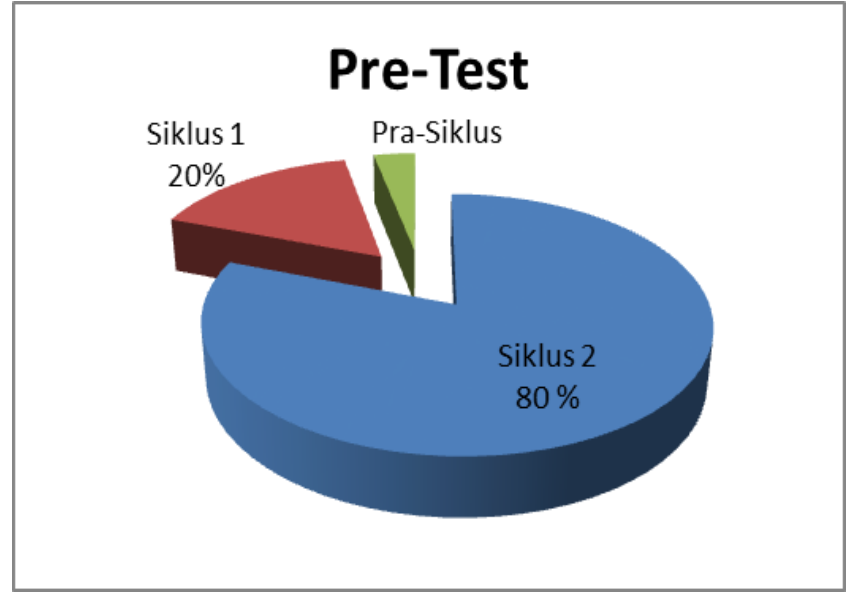

Figure 2. Comparison Graph of the Average LEA Approach in Pre-cycle, Cycle 1 and Cycle II

From the graph of the comparison of the average writing ability in developing paragraphs using the LEA above, it can be seen that from pre-cycle to cycle 1 , the student average increased by 13.7 points with an increase of $20 \%$. Meanwhile, from cycle I to cycle II, the average writing ability of students increased by 2.4 points with a percentage increase of $80 \%$.

Based on the results of the implementation and observations obtained from the study, it shows that in cycle I learning is already very good than cycle II. However, there is still an increase, although not very significant. Increased writing ability to develop paragraphs in English is indicated by the average writing ability of 
students and the increase in the achievement of the LEA approach has reached indicators of success. So that researchers and lecturers decide there is no need to hold the next cycle.

\section{CONCLUSION}

Based on the learning activities which have occurred the enhancing from the first to second cycles from this research findings, it showed that LEA could improve the students' writing ability.

\section{REFERENCES}

Akhadiah M.K., Sabarti et al. 1991/1992. Indonesian I. Jakarta: Directorate General of Higher Education, Depdikbud.

Arikunto, Suharsimi. 2010. Research Procedure: A Practice Approach. Jakarta: Rineka Cipta

Bogdan, R. C., Biklen, S. K., 1992,

Qualitative Research for Education: an Introduction to Theory and Methods. Boston: Allyn \& Bacon.

Brown, Gillian \& Yule, George. 1996.

Discourse Analysis. Jakarta: Gramedia Pustaka Utama.

Brown, G. and Yule, G. 1986. Discourse Analysis. Cambridge: Cambridge University Press.

Cox, Carole. 1999. Teaching Language Arts.
Needham Heights: Allyn \& Bacon.

Crystal, David. 2003. English As Global Language. New York: Cambridge University Press.

Elliot, John. 1991. Action Research For Educational Change. Philadelphia: Open University Press.

Kane, Thomas, S. 1987. The Oxford. The Essential Guide to Writing. New York: Barkley Book.

McNiff. J. 1992. Action Research for Professional Development.

Bournamouth: Hyde Pyblication

Moleong, Lexy J. 1995. Qualitative Research Methodology. Bandung: PT. Rosdakarya youth.

Mulyono, Abdurahman. 1999. Education for Children with Learning Difficulties. Jakarta: Rineka Cipta.

Newman, B.M \& Newman. P.R. (2006). Development Through Life: A Psychosocial Approach. Ninth Edition. Thomson-Wadsworth.

Orr. \& Tracy. (1997). Management, Organization And Practice. (Fikri translation) Yogyakarta: PT Garailmu. 